\title{
Preliminary studies of the effects of bromocriptine on testicular regression and the spring moult in a seasonal breeder, the male blue fox (Alopex lagopus)
}

\author{
A. J. Smith, M. Mondain-Monval*, P. Simon*, K. Andersen Berg $\dagger$, \\ O. P. F. Clausen $\ddagger$, P. O. Hofmo $\dagger$ and R. Scholler*
}

Research Farm for Furbearing Animals, Rustadveien 131, 1380 Heggedal, Norway; *Fondation de Recherche en Hormonologie, 67-77 Boulevard Pasteur, 94260 Fresnes, France; $\dagger$ Department of Reproductive Physiology and Pathology, The Norwegian College of Veterinary Medicine, P.O. Box 8146 Dep., 0033 Oslo 1, Norway; and $\ddagger$ Department of Pathology, Rikshospitalet, Pilestredet 32, 0027 Oslo 1, Norway

\begin{abstract}
Summary. Bromocriptine administration in the form of slow-release injections to male blue foxes during March-May abolished the normal spring rise in plasma prolactin concentrations seen in May and June. The spring moult was prevented and the treated animals retained a winter coat of varied quality and maturity until the end of the study in August.

Plasma testosterone concentrations fell normally from March until August. Testicular regression was, however, delayed, although there were individual variations in response. Estimation by DNA flow cytometry in early July of the relative numbers of haploid, diploid and tetraploid cells in the testis showed that, in the treated animals, $74-80 \%$ of the cells were haploid (maturing germinal cells), 4-6\% tetraploid (mainly primary spermatocytes) and the rest diploid cells (somatic cells and the remaining germinal cell types). In the control males, however, no haploid cells were detected and the majority of cells were diploid (93-99\%). At castration in August, histological examination revealed various stages of testicular regression in the treated and control animals.
\end{abstract}

\section{Introduction}

The male blue fox (Alopex lagopus) is a seasonal breeder, with 5-fold annual changes in testicular size and associated seasonal changes in blood concentrations of a range of hormones (Smith et al., $1984,1985,1986$ ). These variations are probably influenced by seasonal changes in environmental cues such as daylength and temperature, but little is known about the neuroendocrine mechanisms that mediate these cues. Males of other species exhibit variations in plasma concentrations of prolactin that appear to be well correlated to photoperiod, with highest values during long days, both in the Northern hemisphere (e.g. ram: Ravault, 1976; goat: Buttle, 1974; white-tailed deer: Mirarchi et al., 1978) and Southern hemisphere (e.g. ram: Kennaway et al., 1981). The development of a specific radioimmunoassay for prolactin in the blue fox revealed a similar correlation in this species (Smith et al., 1985).

The role of prolactin in the control of male reproductive function is still poorly understood (Bartke, 1980). The effects of prolactin undoubtedly vary depending on the species concerned, the age of the animal and, under experimental conditions, dosage and time of administration. In the golden hamster at least, alterations in prolactin release provide one of the mechanisms that mediate the effect of photoperiod on the testis (for review see Bartke et al., 1985). 
Control of the moulting cycle, on the other hand, and the roles of prolactin and melatonin secretion in the mediation of photoperiodic cues, are more fully understood. We have previously shown that melatonin administration depresses plasma prolactin concentrations in the male blue fox and delays the spring moult (Smith et al., 1987a). A similar situation exists in mink (Allain et al., 1981); in addition, prolactin injections induce an early spring moult (Martinet et al., 1981). Likewise, experimental work in mink suggests that a decline in plasma prolactin concentrations, whether produced by administration of melatonin (Allain et al., 1981), maintenance of the animals under short days (Rose et al., 1985), or bromocriptine treatment (Martinet et al., 1984; Rose et al., 1987) plays a central role in the control of the autumn moult. It is likely that melatonin influences the release of $\mathrm{LHRH}$, dopamine and other factors from the hypothalamus which in turn regulate the secretion of LH, FSH and prolactin from the anterior pituitary (Cardinali, 1981), thereby influencing gonadal activity and fur growth.

Bromocriptine inhibits prolactin release, both by binding to dopamine receptors on anterior pituitary cells (Coronin et al., 1978) and by decreasing dopamine turnover (Fuxe et al., 1978). Bromocriptine has previously been shown to depress plasma prolactin concentrations in, among other species, the male blue fox (Mondain-Monval et al., 1985), male golden hamster (Stroud et al., 1985) and ram (Barenton et al., 1982).

The purpose of the present study was to test, by using bromocriptine, the suspected involvement of prolactin in mediating the effects of melatonin on testicular regression and the spring moult by depressing the physiological rise in plasma prolactin as daylength increases.

\section{Materials and Methods}

Animals. The study took place from March to August 1985 and involved 8 male blue foxes. The animals were approximately 9 months old at the beginning of the study and had shown normal testicular development before the mating season. They were housed individually under natural conditions of daylength and temperature at the Research Farm for Furbearing Animals, Heggedal, Norway (latitude: $59^{\circ} 47^{\prime} \mathrm{N}$; longitude: $10^{\circ} 27^{\prime} \mathrm{E}$ ). The males were within visual and olfactory contact of vixens on the farm but none was allowed to mate during the study period. The mating season during the study was defined as the period between the first and last matings on the farm.

Bromocriptine treatment. A slow-release preparation of bromocriptine adsorbed to microcapsules (CB-154, Sandoz, Basle, Switzerland, providing $25 \mathrm{mg}$ bromocriptine/ml, with a reported release period of 21-28 days) was injected intramuscularly in 4 foxes on 4 occasions (6-8 March, 2-3 April, 29 April and 24 May 1985). All 4 animals were given $4 \mathrm{ml}$ ( $100 \mathrm{mg}$ bromocriptine), injected in 1-ml volumes at 4 different sites, on each date. Four males served as controls.

One of the foxes in the group receiving bromocriptine had to be killed on 14 June because of an injury unrelated to the study.

Blood collection. Blood samples $(10 \mathrm{ml})$ were collected $1-3$ times weekly into heparinized tubes without anaesthesia between $09: 00$ and $11: 00 \mathrm{~h}$, using light manual restraint. Plasma was separated by centrifugation and stored at $-20^{\circ} \mathrm{C}$ until assay.

Hormone assays. Blood samples were analysed for prolactin and testosterone using specific radioimmunoassays previously described and validated for use in the blue fox (prolactin: Mondain-Monval et al., 1985; testosterone: Møller et al., 1984). For the prolactin assay, the sensitivity was $2 \mathrm{ng} / \mathrm{ml}$ and the intra- and inter-assay coefficients of variation were $8.1 \%$ and $13.9 \%$ respectively. The corresponding values for the testosterone assay were $20 \mathrm{pg} / \mathrm{ml}, 4.9 \%$ and $11.7 \%$, respectively. Plasma concentrations of FSH were measured by a heterologous radioimmunoassay (unpublished). This assay utilized an anti-human FSH antiserum (M91/1) donated by A. S. McNeilly, a purified canine FSH preparation (LER-1685-3A) as reference standard and a highly purified ovine FSH (LER-1976-A2) for iodination as tracer, provided by L. E. Reichert. The mean detection limit was $20 \mathrm{ng} / \mathrm{ml}$ and the intra- and inter-assay coefficients of variation were $6.0 \%$ and $10.6 \%$, respectively.

All serial samples from the same animal were measured in duplicate in one assay.

Measurement of testicular volume. The length (which included the head of the epididymis) and width of the testes of all males were measured through the scrotum by using calipers, with no allowance for scrotal skin thickness, at approximately 10-day intervals during the study period. Values for length (2a) and width (2b) were converted to volumes (V) by means of the formula for a prolate spheroid, $\mathrm{V}=1 \cdot 33 \pi \mathrm{ab}^{2}$ (Wildt et al., 1982).

DNA flow cytometry. On 3 July 1985 testicular biopsies were taken from 6 of the 7 males still alive, as described previously (Smith et al., 1987a). The aspirated material was stored in $70 \%$ ethanol until preparation for DNA flow cytometry (Smith et al., 1987a), which enables classification of testicular cells into 3 categories (haploid, diploid or 
tetraploid) depending upon the DNA content of the cell nuclei. The haploid population consists of spermatids and spermatozoa, the tetraploid population mainly of primary spermatocytes, and diploid cells include the remaining germinal cell types and all testicular somatic cells (Smith et al., 1984).

Histological examination of testicular material. All the males were castrated on 14-15 August 1985, and midline sections of each testis fixed for $24 \mathrm{~h}$ in Bouin's solution. The material was then stored in $70 \%$ ethanol before preparation for routine sectioning at $4 \mu \mathrm{m}$ and staining with haematoxylin and eosin.

Sections of testis were examined by light microscopy and 200 cross-sections of tubuli per fox were classified into four categories according to the stage of spermatogenesis. The categories were the presence of (1) spermatogonia only, (2) spermatogonia and primary spermatocytes, (3) spermatogonia, spermatocytes and round spermatids and (4) spermatogonia, spermatocytes and elongated spermatids, with or without round spermatids. The normal seasonal variations in the occurrence of these categories in both immature and adult males have been described elsewhere (Smith et al., 1986, 1987b).

Examination of fur. The males were killed on 14-15 August 1985 and the skins sent to Oslo Fur Auctions where they were assessed for pigmentation, maturation of the fur, hair quality, coat density and texture.

\section{Results}

\section{Plasma prolactin}

As shown in Fig. 1(a) a normal rise in prolactin concentrations occurred in the controls, from $2 \cdot 7-9.7 \mathrm{ng} / \mathrm{ml}$ in March (mean $4.9 \mathrm{ng} / \mathrm{ml}, n=12$ ) to $7.3-20.7 \mathrm{ng} / \mathrm{ml}$ in May and June (mean $12.4 \mathrm{ng} / \mathrm{ml}, n=28$ ). This rise was totally abolished in the treatment group, in which plasma prolactin concentrations remained low throughout the study period $(2 \cdot 1-6 \cdot 0 \mathrm{ng} / \mathrm{ml})$.

\section{Plasma FSH}

Plasma FSH concentrations (Fig. lb) remained low throughout the study period in the control and treatment group (controls: non-detectable $-100 \mathrm{ng} / \mathrm{ml}$; treated: non-detectable $-44 \mathrm{ng} / \mathrm{ml}$ ).

\section{Plasma testosterone}

Plasma concentrations of testosterone fell gradually in a similar way in the control and treated animals (Fig. Ic) from March (controls: $0.51-9.36 \mathrm{ng} / \mathrm{ml}$, mean $5 \cdot 1 \mathrm{ng} / \mathrm{ml}, n=12$; treated: $0.78-$ $4.35 \mathrm{ng} / \mathrm{ml}$, mean $2 \cdot 1 \mathrm{ng} / \mathrm{ml}, n=8$ ) to July and August (controls: $0.03-2.59 \mathrm{ng} / \mathrm{ml}$, mean $0.4 \mathrm{ng} / \mathrm{ml}$, $n=24$; treated: $0.02-1.06 \mathrm{ng} / \mathrm{ml}$, mean $0.4 \mathrm{ng} / \mathrm{ml}, n=18$ ).

\section{Testicular regression}

Testicular regression, as judged by testicular volume, appeared to be delayed in the treated animals compared with the controls (Fig. 1d). Comparison of testicular weights at castration on 14-15 August, however, indicated that only 1 of the treated males (110E) had heavier testes than the other animals by this time.

\section{DNA flow cytometry}

Table 1 depicts the relative numbers (\%) of haploid, diploid and tetraploid cells in testicular biopsies taken on 3 July 1985 from 6 of the 7 males still alive. By this time, the testes of the control animals contained predominantly diploid cells (93-99\%), the remaining cells being tetraploid. In contrast, both of the treated animals biopsied had large haploid cell populations (spermatids or spermatozoa) amounting to $74-80 \%$ of the testicular cells. The tetraploid cell populations were similar in relative size to the controls $(4-10 \%)$ and the diploid populations were consequently smaller $(12-14 \%)$. 


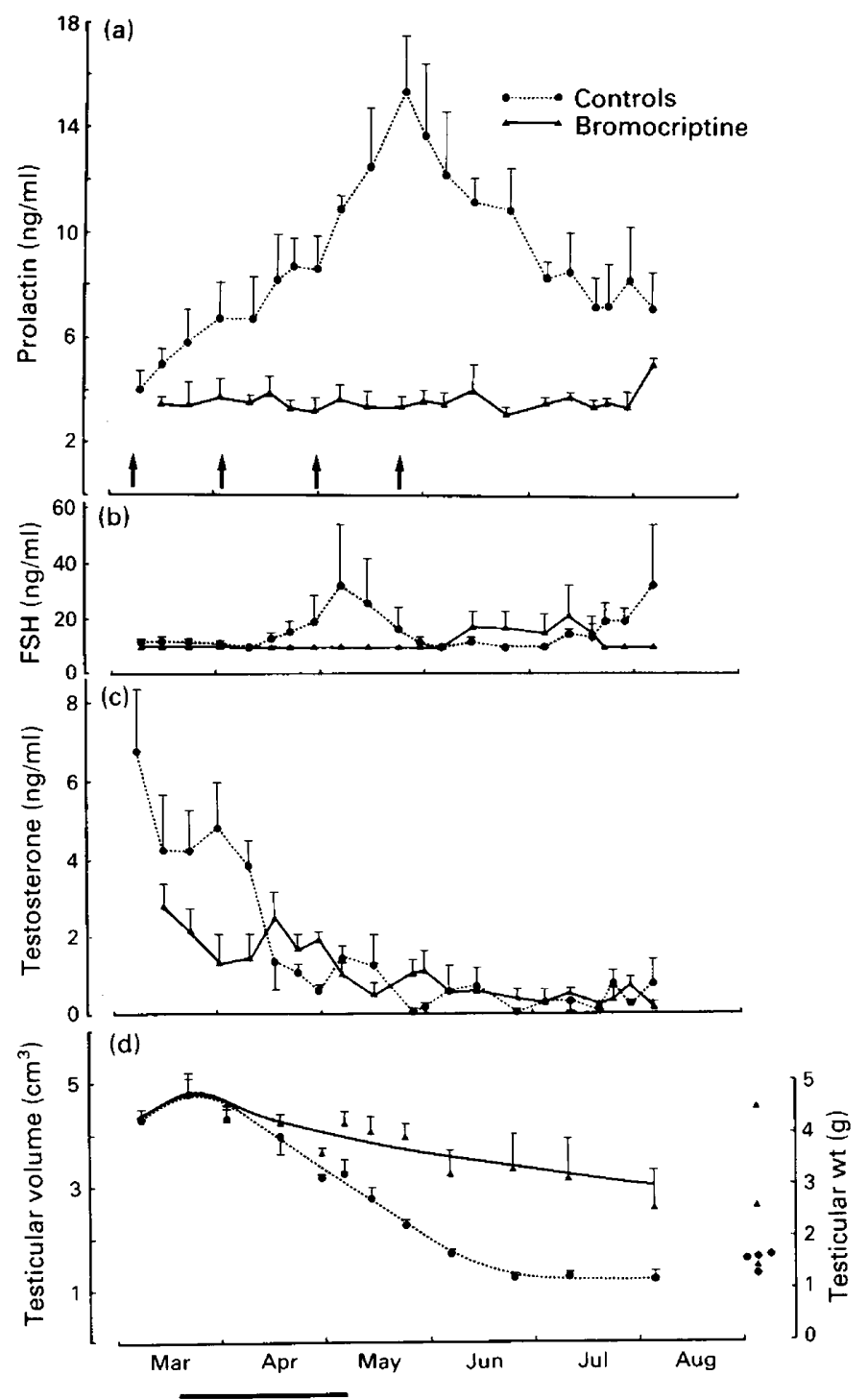

Fig. 1. Variations in (a) plasma prolactin, (b) plasma FSH, (c) plasma testosterone and (d) testicular volume in a group of 4 foxes treated 4 times at 25-27-day intervals with a slow-release preparation of bromocriptine and 4 untreated controls, from March until May 1985. The arrows in (a) depict the dates of administration of bromocriptine. The horizontal bar under the figure indicates the duration of the mating season on the farm during the study. The symbols at the bottom right of the figure depict the mean testicular weights of the individual males at castration on 14-15 August 1985. Values are means \pm s.e.m. for all the animals in each group. One of the animals receiving bromocriptine was killed on 14 June because of an injury unrelated to the study.

\section{Histological examination of the testes}

The relative proportions of 4 tubular categories in the testes of the males at castration in August 1985 are shown in Table 2 . In the control group, virtually all tubular sections (92-99\%) contained spermatogonia as the most advanced germinal cells, the remainder (1-8\%) containing also primary 
Table 1. Relative numbers (\%) of haploid, diploid and tetraploid cells in testicular biopsies taken on 3 July 1985 from 6 of the 8 animals

\begin{tabular}{lccc}
\hline & Haploid & Diploid & Tetraploid \\
\hline Controls & & & \\
167E & 0 & 93.3 & 6.7 \\
168E & 0 & 98.1 & 1.9 \\
$298 \mathrm{E}$ & 0 & 98.1 & 1.9 \\
$312 \mathrm{E}$ & 0 & 98.6 & 1.4 \\
Bromocriptine-treated & & \\
110E & 74.4 & 11.9 & 3.7 \\
$306 \mathrm{E}$ & $80 \cdot 1$ & 14.0 & 5.9 \\
\hline
\end{tabular}

Table 2. The relative numbers ( $\%$ ) of 4 categories of seminiferous tubules in the testis at castration on 14-15 August 1985

\begin{tabular}{lrrrr}
\hline & \multicolumn{4}{c}{ Tubular category* } \\
\cline { 2 - 5 } & 1 & 2 & 3 & 4 \\
\hline Controls & 96 & 4 & 0 & 0 \\
$167 \mathrm{E}$ & 92 & 8 & 0 & 0 \\
$168 \mathrm{E}$ & 99 & 1 & 0 & 0 \\
$298 \mathrm{E}$ & 92 & 8 & 0 & 0 \\
$312 \mathrm{E}$ & 0 & 6 & 43 & 51 \\
Bromocriptine-treated & & & \\
$110 \mathrm{E}$ & 70 & 30 & 0 & 0 \\
$306 \mathrm{E}$ & 95 & 5 & 0 & 0 \\
$103 \mathrm{E}$ & & & \\
\hline
\end{tabular}

*1, Spermatogonia only; 2 , spermatogonia and primary spermatocytes; 3 , spermatogonia, spermatocytes and round spermatids; 4 , spermatogonia, spermatocytes and elongated spermatids, with or without round spermatids.

spermatocytes. The treatment group showed great differences between individuals. In one of the 3 animals, the tubular sections resembled those seen in the control group (103E: category 1, 95\%; category $2,5 \%$ ). Another male (306E) showed a shift towards more mature germinal cell types ( $70 \%$ of tubules containing spermatogonia only and $30 \%$ also containing primary spermatocytes), but the primary spermatocytes were clearly degenerate. The third male $(110 \mathrm{E})$, in contrast, had no tubules with only spermatogonia, and only $6 \%$ with primary spermatocytes as the most advanced germinal cells. In this male, $43 \%$ of tubular sections contained cells up to the round spermatid stage, and $51 \%$ of tubules contained elongated spermatids. However, in this fox the tubular lumen was absent, indicating that spermiation had not taken place.

\section{Moulting cycle}

The control animals underwent a normal moult during May and June. None of the treated males, however (including the fox which was kilied on 14 June), lost their winter coat. The typical appearance in July 1985 of males in the control group and of those receiving bromocriptine is illustrated in Fig. 2. All 3 of the foxes given bromocriptine had mature winter pelts, with normal 

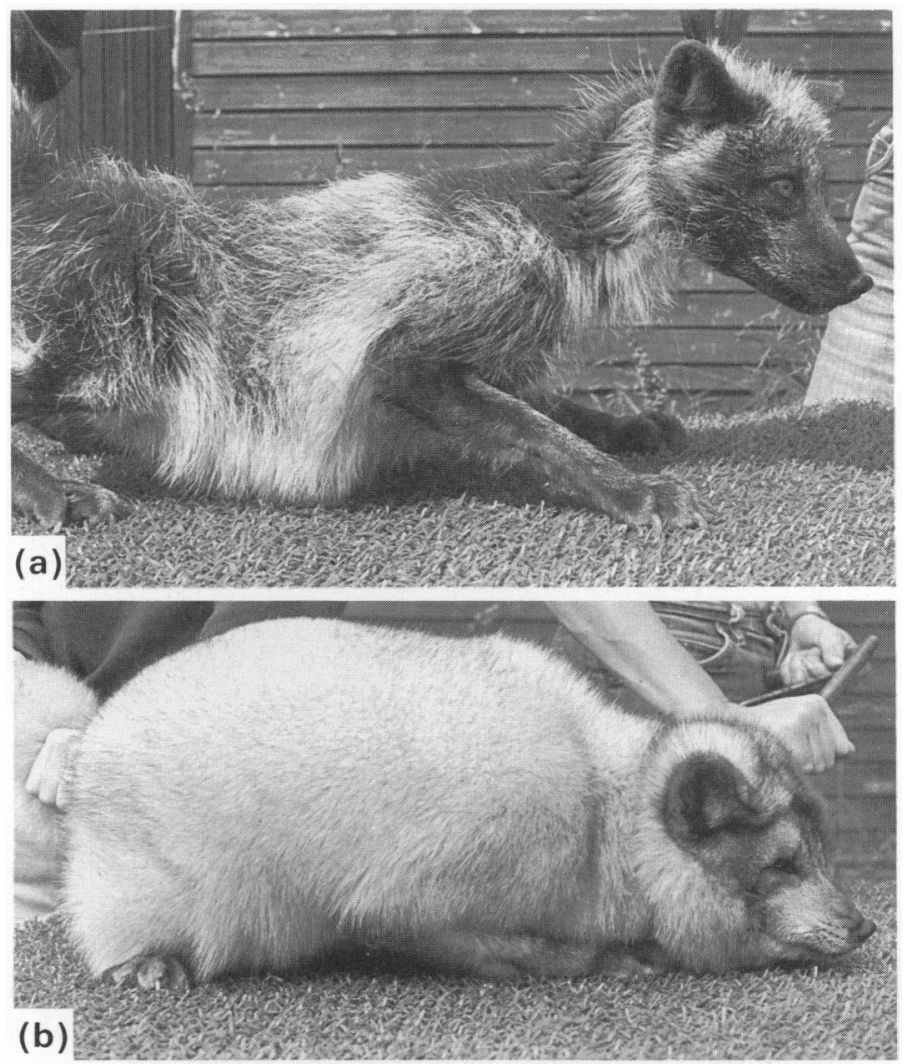

Fig. 2. Appearance in July 1985 of (a) control animals and (b) males treated with bromocriptine from March to May 1985.

hair quality, texture and density. Two of the pelts gave the impression of having undergone a change of hair pigment, especially in the guard hairs, to a uniform beige/yellow colour. The third was discoloured by urine.

\section{Discussion}

The present study shows that bromocriptine treatment initiated in March suppresses the annual rise in plasma prolactin concentrations that normally occurs during increasing daylength (MayJune) and prevents the spring moult. Previous (unpublished) studies have shown the same effect even when bromocriptine treatment was begun as late as May, after plasma prolactin concentrations have started to increase; these males retained the winter coat through the following winter and moulted normally in the spring.

Bromocriptine treatment appeared also to influence testicular regression, despite the fact that testosterone concentrations remained unchanged. The mechanism of this effect is unclear: bromocriptine treatment has been reported to stimulate FSH release in sheep (Ravault et al., 1982), but no such effect was seen in the present study (Fig. 1b). High doses of bromocriptine may also interfere with other hormones, in particular LH (Shaban \& Terranova, 1986), growth hormone (Flückiger $e t$ al., 1976) and MSH (Penny et al., 1979).

Prolactin is believed to modify the sensitivity of the hypothalamic-pituitary axis to testosterone 
feedback during testicular regression of the golden hamster (Matt et al., 1984). There is, however, no evidence for this in the blue fox; suppression of the spring rise in plasma prolactin concentrations by melatonin does not appear to alter $\mathrm{LH}$ release despite the fact that testosterone production is prolonged (Smith et al., 1987a). A decrease in testosterone secretion does not appear to be the primary stimulus for the spring moult since this moult and the simultaneous rise in plasma prolactin concentrations continue normally after castration (Smith et al., 1985).

Other studies also indicate that there is no fixed relationship between the rise in plasma prolactin concentrations and the breeding season. Carr \& Land (1982) observed simultaneous prolactin rises in castrated rams of 3 breeds of sheep with different seasonality of reproduction. Likewise, while some species of deer have high blood concentrations of gonadotrophins (e.g. roe deer: Schams \& Barth, 1982), others (e.g. white-tailed deer: Mirarchi et al., 1978) have low gonadotrophin concentrations when prolactin values are high. This is in agreement with our own (unpublished) studies of seasonally-breeding canid furbearers with different mating seasons.

It is still unclear whether the rise in prolactin is triggered by increasing daylength or temperature. The effects of these 2 variables are impossible to differentiate under natural conditions since both show marked and parallel annual changes at this latitude (Smith et al., 1985). Plasma prolactin concentrations in golden and Djungarian hamsters, maintained in constant temperature, change readily in response to photoperiod (Bex et al., 1978; Duncan \& Goldman, 1984). Studies of other species, however, have demonstrated a rise in prolactin values in response to increasing temperature (cattle: Tucker \& Wettemann, 1976; rat: Mueller et al., 1974).

Studies of mink indicate that both the furring cycle and testicular development may also be influenced by $\alpha$-MSH secretion (Ellis et al., 1982). Work on the Djungarian hamster (Duncan \& Goldman, 1984), however, suggests that the effects of bromocriptine on the pelage colour cycle are mediated by prolactin suppression alone, without any suppression of MSH. Burchill \& Thody (1986) suggest direct effects of dopaminergic agents on hair follicles. Further studies are clearly warranted before the changes seen in the present study after bromocriptine treatment can be ascribed to the reduction in plasma prolactin concentrations.

We thank Dr L. E. Reichert for the ovine prolactin; Dr A. S. McNeilly for the prolactin and FSH antisera; Dr H. Papkoff for the canine prolactin; Hans Sørensen (Oslo Fur Auctions) for assessing the pelts of the animals in this study; and Margaret Dahl and Sigbjørn Dalum for skilful technical assistance. The CB-154 was generously donated by Sandoz A.G., Basle, Switzerland.

\section{References}

Allain, D., Martinet, L. \& Rougeot, J. (1981) Effect of melatonin implants on changes in the coat, plasma prolactin level and testis cycle in the mink (Mustela vison). In Photoperiodism and Reproduction, pp. 263-271. Eds R. Ortavant, J. Pelletier \& J.-P. Ravault. INRA, Nouzilly.

Barenton, B., Hochereau-de Reviers, M.T., Perreau, C. \& Poirier, J.C. (1982) Effects of induced hypoprolactinaemia in the ram: plasma gonadotrophin levels, LH and FSH receptors and histology of the testis. Reprod. Nutr. Dévelop. 22, 621-630.

Bartke, A. (1980) Role of prolactin in reproduction in male mammals. Fedn Proc. Fedn Am. Socs exp. Biol. 39, 2577-2581.

Bartke, A., Klemcke, H. \& Matt, K. (1985) Effects of physiological and abnormally elevated prolactin levels on the pituitary-testicular axis. Medical Biology $63,264-272$.

Bex, F., Bartke, A., Goldman, B.D. \& Dalterio, S. (1978)
Prolactin, growth hormone, luteinizing hormone receptors, and seasonal changes in testicular activity in the golden hamster. Endocrinology 103, 2069-2080.

Burchill, S.A. \& Thody, A.J. (1986) Dopaminergic inhibition of tyrosinase activity in hair follicular melanocytes of the mouse. J. Endocr. 111, 233-237.

Buttle, H.L. (1974) Seasonal variation of prolactin in plasma of male goats. J. Reprod. Fert. 37, 95-99.

Cardinali, D.P. (1981) Melatonin. A mammalian pineal hormone. Endocr. Rev. 2, 327-346.

Carr, W.R. \& Land, R.B. (1982) Seasonal variations in plasma concentrations of prolactin in castrated rams of breeds of sheep with different seasonality of reproduction. J. Reprod. Fert. 66, 231-235.

Coronin, M.J., Roberts, J.M. \& Weiner, R.I. (1978) Dopamine and dihydroergocryptine binding to the anterior pituitary and other brain areas of the rat and sheep. Endocrinology 103, 302-309.

Duncan, M.J. \& Goldman, B.D. (1984) Hormonal 
regulation of the annual pelage color cycle in the Djungarian hamster, Phodopus sungorus. II Role of prolactin. J. exp. Zool. 230, 97-103.

Ellis, L.C., Groesbeck, M.D. \& Howell, R.E. (1982) Pineal gland-pituitary ( $\alpha$-MSH) interrelationships in fur priming and reproductive cycles in mink (Mustela vison). Prog. Clin. Biol. Res. 92, 197-205.

Flückiger, E., Marko, M., Doepfner, W. \& Niederer, W. (1976) Effects of ergot alkaloids on the hypothalamicpituitary axis. Postgrad. Med. J. 52 (Suppl. 1), 57-61.

Fuxe, K., Fredholm, B.B., Ögren, S.O., Agnati, L.F., Hökfelt, T. \& Gustafsson, J.A. (1978) Pharmacological and biochemical evidence for the dopamine agonistic effect of bromocryptine. Acta endocr., Copenh. 88 (Suppl. 216), 27-56.

Kennaway, D.J., Obst, J.M., Dunstan, E.A. \& Friesen, H.G. (1981) Ultradian and seasonal rhythms in plasma gonadotropins, prolactin, cortisol and testosterone in pinealectomized rams. Endocrinology 108, 639-646.

Martinet, L., Meunier, M.C. \& Allain, D. (1981) Control of delayed implantation and onset of spring moult in the mink (Mustela vison) by daylight ratio, prolactin and melatonin. In Photoperiodism and Reproduction, pp. 253-261. Eds R. Ortavant, J. Pelletier \& J.-P. Ravault. INRA, Nouzilly.

Martinet, L., Allain, D. \& Weiner, C. (1984) Role of prolactin in the photoperiodic control of moulting in the mink (Mustela vison). J. Endocr. 103, 9-15.

Matt, K.S., Bartke, A., Soares, M.J., Talamantes, F., Hebert, A. \& Hogan, M.P. (1984) Does prolactin modify testosterone feedback in the hamster? Suppression of plasma prolactin inhibits photoperiod-induced decreases in testosterone feedback sensitivity. Endocrinology 115, 2098-2103.

Mirarchi, R.E., Howland, B.E., Scanlon, P.F., Kirkpatrick, R.L. \& Sanford, L.M. (1978) Seasonal variation in plasma $\mathrm{LH}, \mathrm{FSH}$, prolactin and testosterone concentrations in adult male white-tailed deer. Can. J. Zool. 56, 12 I-127.

Møller, O.M., Mondain-Monval, M., Smith, A., Metzger, E. \& Scholler, R. (1984) Temporal relationships between hormonal concentrations and the electrical resistance of the vaginal tract of blue foxes (Alopex lagopus) at pro-oestrus and oestrus. J. Reprod. Fert. 70, 15.24.

Mondain-Monval, M., Møller, O.M., Smith, A.J., McNeilly, A.S. \& Scholler, R. (1985) Seasonal variations of plasma prolactin and LH concentrations in the female blue fox (Alopex lagopus). J. Reprod. Fert. 74, $439-448$.

Mueller, G.P., Chen, H.T., Dibbet, J.A., Chen, H.J. \& Meites, J. (1974) Effects of warm and cold temperatures on release of $\mathrm{TSH}, \mathrm{GH}$, and prolactin in rats. Proc. Soc. exp. Biol. Med. 147, 698-700.

Penny, R.J.. Tilders, F.J.H. \& Thody, A.J. (1979) The role of the dopaminergic tubero-hypophysial neurones in the maintenance of 'basal' melanocytestimulating hormone levels in the rat. $J$. Endocr. 80, 58P-59P.

Ravault, J.P. (1976) Prolactin in the ram: seasonal variation in the concentration of blood plasma from birth to three years old. Acta endocr., Copenh. 83, 720-725.

Ravault, J.P., Barenton, B., Blanc, M., Daveau, A., Garnier, D.H., Ortavant, R., Pelletier, J., de Reviers,
M.-M. \& Terqui, M. (1982) Influence of 2 Br- $\alpha$-ergocryptine (CB 154) on the secretion of prolactin, LH, FSH and testosterone and on testicular growth in rams subjected to different photoperiods. Reprod. Nutr. Dévelop. 22, 989-998.

Rose, J., Stormshak, F., Oldfield, J. \& Adair, J. (1985) The effects of photoperiod and melatonin on serum prolactin levels of mink during the autumn molt. $J$. Pineal Res. 2, 13-19.

Rose, J., Oldfield, J. \& Stormshak, F. (1987) Apparent role of melatonin and prolactin in initiating winter fur growth in mink. Gen. comp. Endocr. 65, 212-215.

Schams, D. \& Barth, D. (1982) Annual profiles of reproductive hormones in peripheral plasma of the male roe deer (Capreolus capreolus). J. Reprod. Fert. 66, 463-468.

Shaban, M.A. \& Terranova, P.F. (1986) 2-bromo- $\alpha-$ ergocryptine mesylate (CB-154) inhibits prolactin and luteinizing hormone secretion in the prepubertal female rat. Biol. Reprod. 34, 788-795.

Smith, A.J., Clausen, O.P.F., Kirkhus, B., Jahnsen, T., Møller, O.M. \& Hansson, V. (1984) Seasonal changes in spermatogenesis in the blue fox (Alopex lagopus), quantified by DNA flow cytometry and measurement of soluble $\mathrm{Mn}^{2+}$-dependent adenylate cyclase activity. J. Reprod. Fert. 72, 453-461.

Smith, A.J., Mondain-Monval, M., Møller, O.M., Scholler, R. \& Hansson, V. (1985) Seasonal variations of $\mathrm{LH}$, prolactin, androstenedione, testosterone and testicular FSH binding in the blue fox (Alopex lagopus). J. Reprod. Fert. 74, 449-458.

Smith, A.J., Bugge, H.P., Andersen Berg, K., Moller, O.M. \& Hansson, V. (1986) Seasonal changes in testicular structure and function in the blue fox (Alopex lagopus), quantified by morphometrical analysis and adenylate cyclase activity. Int. J. Androl. 9, 53-66.

Smith, A.J., Mondain-Monval, M., Andersen Berg, K., Simon, P., Forsberg, M., Clausen, O.P.F., Hansen, T., Møller, O.M. \& Scholler, R. (1987a) Effects of melatonin implantation on spermatogenesis, the moulting cycle and plasma concentrations of melatonin, LH, prolactin and testosterone in the male blue fox (Alopex lagopus). J. Reprod. Fert. 79, 379-390.

Smith, A.J., Mondain-Monval, M., Andersen Berg, K., Gordeladze, J.O., Clausen, O.P.F., Simon, P. \& Scholler, R. (1987b) Sexual development in the immature male blue fox (Alopex lagopus), investigated by testicular histology, DNA flow cytometry and measurement of plasma FSH, LH, testosterone and soluble testicular $\mathrm{Mn}^{2+}$-dependent adenylate cyclase activity. J. Reprod. Fert. 81, 505-515.

Stroud, C.M., Noden, P.F. \& Whitsett, J.M. (1985) Bromoergocryptine decreases serum prolactin and delays sexual maturation in male golden hamsters. Biol. Reprod. 32, 1191-1199.

Tucker, H.A. \& Wettemann, R.P. (1976) Effects of ambient temperature and relative humidity on serum prolactin and growth hormone in heifers. Proc. Soc. exp. Biol. Med. 151, 623-626.

Wildt, D.E., Baas, E.J., Chakraborty, P.K., Wolfle, T.L. \& Stewart, A.P. (1982) Influence of inbreeding on reproductive performance, ejaculate quality and testicular volume in the dog. Theriogenology 17, 445 452 .

Received 9 April 1987 